\title{
UTICAJ KLIMATSKIH PROMENA NA ARHITEKTURU GRADOVA
}

Predrag Mihajlović ${ }^{1}$

UDK: $711.417 / .436: 551.583$

DOI: 10.14415/konferencijaGFS 2016.096

Apstrakt: $U$ ovom radu biće reči o uticaju sveprisutnijih promena klime na promene $u$ arhitekturu, prvenstveno u urbanim sredinama. Polazi se od hipoteze da svest o klimatskim promenama nužno uslovljava razvoj novih i inovativnih tehnika, tehnologija, principa ekološkog arhitektonsko-urbanističkog projektovanja, odnosno do izmena koncepta savremene arhitekture gradova. Savremena arhitektura, u svetlu evidentnih klimatskih promena, ne nastoji da bude samo "znalačka, pravilna i raskošna igra oblika okupljenih na svetlosti" (Le Corbusier), već nastoji da utiče na okruženje kreiranjem mikro-klimatskih zona u unutrašnjem i spoljašnjem prostoru, insistirajući, pri tome, na nultom energetskom utrošku. Prema tome, pred savremenom ali još $i$ više, pred arhitekturom u budućnosti postavlja se zahtev za održivosti, to u saradnji sa održivim razvojem okruženja i unapređenom ekološkom svesti u pogledu zaštite životne sredine.

Ključne reči: arhitektura, urbana sredina, klimatske promene

Prodor novog i jedinstvo sa drugim se mora anticipirati kao nepredvidivo, kao nešto o čemu još nemamo pamćenje.

Jacques Derrida

\section{UVOD}

Poslednjih decenija svedoci smo očiglednih promena klime. I ranije se klima menjala, ali, isključivo kao rezultat promena prirodnih okolnosti. Sa brzim razvojem industrije $\mathrm{i}$ porastom populacije primat u promeni klime preuzima ljudski faktor. Smatra se da će i u budućnosti taj uticaj rasti i da će njegove posledice u najvećoj meri biti globalno nepovoljne po život na planeti Zemlji. Zabrinjavajuće je da ni eksperti koji se bave ovom problematikom nemaju u potpunosti usaglašena mišljenja vezana za tačne uzroke i posledice klimatskih promena. Zagrevanje planete dokazano je i ono je bespovratno, a njegova najbolnija posledica jeste to što raste nivo mora i time veći deo kopna postaje nepodesan za život. Oni koji su ovo ozbiljno shvatili su arhitekte, koji već projektuju gradove prilagođene uslovima koji će zavladati na planeti. Šta se podrazumeva pod pojmom klimatske promene i kakav je njihov uticaj na arhitekturu gradova? Pred postindustrijskim društvom stoji veliki izazov koji se može

\footnotetext{
${ }^{1}$ Ministarstvo građevinarstva, saobraćaja i infrastrukture Republike Srbije, e-mail: predrag.mihajlovic@mgsi.gov.rs
} 
Contemporary achievements in civil engineering 22. April 2016. Subotica, SERBIA

sagledati kroz pitanja: Kakav grad je nužan? Kakva grad je moguć?, ne bi li se odgovorilo na izazove globalnih i naglih promena. Odgovore na ova složena pitanja, kao i na mnoga druga, arhitektura više nije u stanju da da sama na tradicionalan način. Imajući u vidu sve dosadašnje trendove, može se reći da ključ odgovora leži u društvenoj, tačnije javnoj sferi, u smislu redefinisanja sistema i uspostavljanja novog u skladu sa novonastalom realnošću. Današnja realnost pretpostavlja visok stepen tehnološkog razvoja sa tendencijom stalnog unapređenja, što za rezultat ima multidimenzionalni dinamični okvir razvoja i života na globalnom nivou.

\section{DEFINICIJE KLIMATSKIH PROMENA}

U naučnoj javnosti postoji saglasnost da se promene klime pripisuju aktivnostima koje menjaju sastav atmosfere a koje se evidentiraju u dužem intervalu vremena. Sam termin „klimatske promene“ koristi se za opis promena klime do kojih dolazi kao rezultat prirodnih $\mathrm{i} / \mathrm{ili}$ ljudskih faktora. U 4. izveštaju Međuvladinog panela o klimatskim promenama (Intergovernmental Panel on Climate Change - IPCC), grupa naučnika i stručnjaka za klimatske promene tvrdi: „Klima se menja i te klimatske promene su uglavnom nastale zbog ljudskog delovanja“ [1]. Među osnovnim zaključcima ovog izveštaja argumentuje i podvlači da je efekat staklene bašte evidentan, a emisije gasova staklene bašte koje nastaju ljudskim aktivnostima značajno utiču na pojačano zagrevanje atmosfere. Zbog toga, akcenat je na tome kako smanjiti prevashodno uticaj čoveka na klimu, u prvom koraku, a zatim i kako se prilagoditi promenama koje su već nastale ili se pojavljuju, imajući u vidu da pomenuti procesi utiču globalno: na planetu ali i na sav živi svet, uključujući i čoveka. Planeta Zemlja i njen ekosistem su postali veoma ranjivi a time i čovek kao deo tog sistema. Sa stanovišta ekonomskih proizvodnih procesa, inerciju porasta koncentracije gasova staklene bašte je teško promeniti i zaustaviti u kratkom vremenskom periodu. Međutim, u dovoljno dugom periodu, smatra se da se prvi pozitivni rezultati mera $\mathrm{i}$ aktivnosti koje se sada preduzimaju mogu očekivati ne pre druge polovine XXI veka. Ljudima preostaje da se prilagode a taj proces adaptacije biće naročito težak u gradskim sredinama, gde već postoje građevine građene prema arhitekturama i stilovima $u$ izgradnji koji su bili autentični za periode kada se o klimatskim promenama nije ni govorilo, zato što nisu ni bile evidentne ili zato što se o njima nije ni znalo.

\section{POSLEDICE KLIMATSKIH PROMENA I UTICAJ NA KVALITET ŽIVOTA U URBANIM SREDINAMA}

Posledice klimatskih promena - globalnog zagrevanja svakog dana su sve vidljivije. Ubrzano zagrevanje atmosfere izaziva brojne posledice, što rezultuje mnogim štetnim efektima: porast globalne temperature što dovodi do zabrinjavajućeg i potencijalno kataklizmički opasnog podizanja nivoa svetskog mora, topljenje leda na polovima i glečerima, kao i promena režima padavina, koje vode do problema sa nesagledivim posledicama. Nivo mora u XXI veku će, prema IPCC-u, porasti za $18-38 \mathrm{~cm}$ u najpovoljnijem slučaju, dok prema najgorem scenariju nivo mora može 
porasti za $26-59 \mathrm{~cm} \mathrm{[3].} \mathrm{Porast} \mathrm{nivoa} \mathrm{mora} \mathrm{je} \mathrm{posledica} \mathrm{otapanja} \mathrm{glečera,} \mathrm{ali} \mathrm{i} \mathrm{širenja}$ celokupne vodene mase usled toplotnog efekta. Takođe, klimatske promene dovode i do povećanja broja ekstremnih vremenskih događaja (oluja, poplava,...). O ovome govori i podatak da su se velike poplave ranije javljale otprilike na svakih 100 godina, dok se u budućnosti očekuje da će se javljati znatno češće.

Posledice klimatskih promena se ogledaju i u tome što uzrokuju izumiranje biljnih i životinjskih vrsta, ali i pojavu novih. Takođe, prouzrokuju značajne probleme u funkcionisanju ljudskog društva. Proizvodnja i dostupnost hrane i vode, zdravlje ljudi, samo su neke od pojava koje se mogu bitno promeniti. Klimatske promene mogle bi da uslove i brojne društvene probleme poput masovnih seoba, velikih sukoba oko malo preostalog obradivog zemljišta, vodenih resursa itd.

Najozbiljnija posledica porasta nivo mora je što će mnogi priobalni gradovi i naselja biti potopljeni. U spoju sa globalnim zagrevanjem, pojačaće se isparavanje mora a s tim i oblačnost. Ovo može da uzrokuje smanjeno osunčavanje useva tako da može da problem gladi na svetskom nivou. Drastičan je primer Floride za koju je procenjeno da će, ako podizanje nastavi ovim tempom, za sto godina biti potpuno potopljena, zajedno sa Majamijem - višemilionskim gradom. Ovaj primer je pomogao da se ljudi zapitaju dokle će uništavati planet i šta mogu uraditi sa različitih aspekata da se krize preduprede. Širom sveta su pokrenute akcije za smanjenje emisije štetnih gasova s kojima se utiče na smanjenje stepena podizanja mora.

Ako sagledamo sve elemente okruženja, shvatićemo da i kvalitet života savremenog čoveka u urbanim sredinama isključivo zavisi od toga gde, kako i u kojim klimatskim uslovima živimo. Naime, jedna od osnovnih, najbitnijih za čoveka je svakako zabrinutost zdravljem, a klimatske promene neposredno utiču na taj faktor. Dostupnost i ispravnost vode za piće i hrane, i kvalitet vazduha veoma su važni aspekti koji utiču na zdravlje stanovništva. Posledice klimatskih promena po zdravlje i okruženje u narednom

periodu će verovatno biti teške. Povećanjem temperature doći će, lokalno do velikih suša, nestašica vode, a samim tim i do toga da će hrana biti nedostupna manje razvijenim zemljama. Neki delovi planete će, s druge strane, biti pogođeni katastrofalnim poplavama što će takođe imati teške posledice po uslove življenja. Siromašne zemlje će najviše i biti pogođene što je paradoksalno jer su upravo te zemlje najmanje doprinele klimatskim promenama. U kontekstu zdravlja kao najveće brige savremenog čoveka istraživački projekti, koji ispituju efekte klimatskih promena, ukazuju da će doći i do povećanja prenosivih bolesti, što sve loše utiče na kvalitet života, i predstavlja još jedan važan razlog da se hitno pristupi realizaciji raspoloživih mera za smanjenje emisija štetnih gasova i ublažavanje procesa i posledica klimatskih promena. Savremena arhitektura u svetlu uticaja delovanja faktora izazvanih promenom klime, nastoji da putem primene inovativnih projektantskih koncepata, pristupa i strategija, kojima se odgovara na izazove koje pred arhitekturu postavljaju klimatske promene. Gradovi danas zahtevaju od arhitekture promišljanje koje se bazira manje na prostoru, a više na vremenu. Ubrzane transformacije gradova se više ne zasnivaju težišno na transformaciji grada sa generičkom ulogom promene zasnovane na njemu kao fizičkom entitetu, već suprotno, ubrzane promene generisane od strane moderne kulture menjaju percepciju i ulogu grada. Urbana forma i oblik grada se menjaju na osnovu potreba stanovništva, a kako je promenljivost učestala, onda se odgovor traži kroz koncept dematerijalizacije, koristeći tako pametne materijale kako bi 
Contemporary achievements in civil engineering 22. April 2016. Subotica, SERBIA

se zadovoljili zahtevi brzog i lakog modifikovanja fleksibilnih dinamičnih struktura, privremenih i/ili efemernih, zasnovanih na samodovoljnom dizajnu - self-sufficient design. [3]

\section{KLIMATSKE PROMENE I URBANISTIČKO-ARHITEKTONSKO PLANIRANJE}

Istraživanje uticaja klimatskih promena postavlja se i pred arhitekturu kao umetničku i estetsku praksu ki zadire u samu suštinu arhitekture kao naučne discipline i praktične veštine. Oduvek, arhitektura se suočavala sa urbanim problemima, bez obzira da li su društveni, ekološki problemi ili problemi vezani za životno okruženje. Ovog puta, međutim, trebalo bi da nađe nove forme koje ne samo što će poštedeti stanovništvo klimatskog egzodusa, već i nastaviti da čuvaju krhku ravnotežu više gradova.

Jedno od mogućih rešenja je plutajući grad. Iako deluje nerealno ovo rešenje se razmatra u slučaju da podizanje nivoa mora dosegne velike razmere. Ovde je razlika u tome što se tehnička veština kombinuje sa originalnošću forme što daje rezultat koji je ocenjen kao ekološki i održiv. Na taj način, plutajuće kuće - novi i savremeni objekti sa svim mogućim komforom - postaju predmet cvetajuće trgovine.

Dok su ovi plutajući gradovi zamišljeni na periferiji, čak i u samom gradu, kao jedan od aspekata novog urbanizma XXI veka, postoje i drugi projekti, za sada eksperimentalni, koji bi, prema rečima njihovih projektanata, mogli da predstavljaju, u slučaju klimatskih promena, alternativu tradicionalnom životu.

Drugo rešenje zvuči jednako nerealno. To su podvodne kupole u kojima bi bili nastanjeni stanovnici posebno ugroženih priobalnih gradova. Još jedno rešenje koje je privremeno je da se izgrade brane i tako "vrati" deo kopna i na neko vreme spreči rast dalje potapanje...Postoji jos mnogo mogućih rešenja...ali sve u svemu evidentno je da će ljudi kao inteligentna vrsta smisliti nešto što će im omogućiti dalji opstanak.

Takođe je zanimljivo rešenje japanske kompanije Shimizu Corporation (Šimicu Korporejšn) koja je razvila jedinstveni prototip koji bi mogao da ugleda svetlost dana posle 2025. godine. Nazvan Green Float, ovaj grad, čiji bi svaki modul mogao da primi do 50.000 stanovnika, razvijaće se samostalno na okeanu. Module čine osnova od $2 \mathrm{~km}$ u prečniku i kula nazvana City in the sky (Grad na nebu).

Ovaj neboder, zasnovan na lakom metalu nastalom od magnezijuma koji se već nalazi u slanoj vodi, trebalo bi da bude u osnovi okružen sopstvenim obradivim zemljištem kojim se stanovništvu garantuje, zahvaljujući poljoprivredi, potpuna samodovoljnost. Predviđena je čak i reciklaža slane vode iz okruženja. Kula bi mogla da dostigne visinu do $1.000 \mathrm{~m}$ iznad nivoa mora, a ostrvo bi moglo da koristi sve prirodne elemente kako bi postalo autonomno. Pokretanje tehnologije otporne na talase i druge prirodne nepogode danas predstavljaju jedinu prepreku za razvoj ove vrste projekta. Projekat Green float vizija je grada sa negativnom emisijom ugljen-dioksida - umreženih serija nepreglednih plutajućih ćelija koje ne proizvode $\mathrm{CO}_{2}$ i čije stanovništvo je u potpunosti samodovoljno. Svaka ćelija biće kilometar široka i, kada se poveže, moći će da stvori naselje sa populacijom od 50.000 ljudi. Veće mreže moći će čak da stvore gradove od po 100.000 stanovnika. Centar ćelije bio bi toranj visok $1.000 \mathrm{~m}$, dok bi manje stambene jedinice bile raspoređene oko njega. Široka oblast šuma okruživala bi centralni toranj, dok bi nešto 
udaljenije zeleno priobalje i lagune podržavale ekosistem. Oni bi služili izvor hrane brišući time potrebu za uvozom.

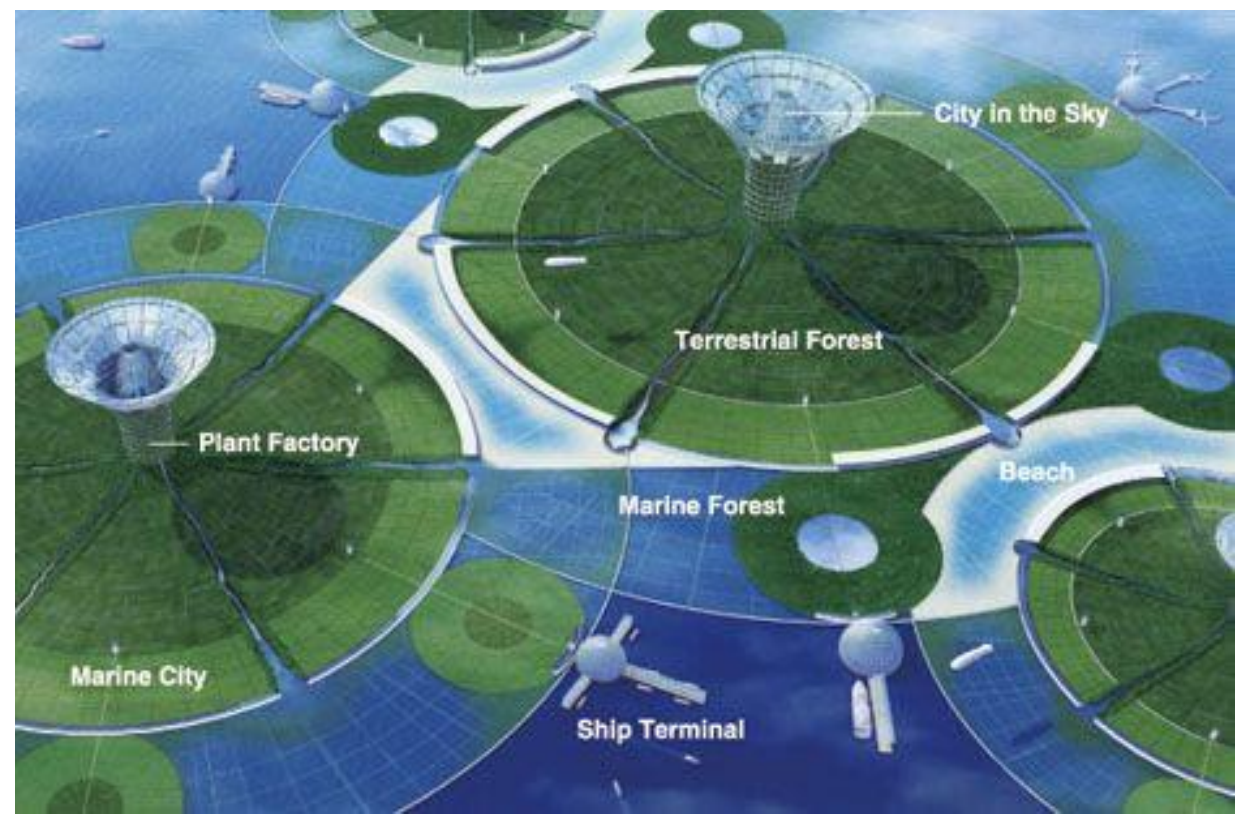

Slika 1. City in the sky (Grad na nebu)

Green Float bio bi grad sa negativnom emisijom ugljen-dioksida. Ovo bi se postiglo nizom mera, uključujući:

- $\quad$ Precizan projekat samih gradova - što bi dovelo do smanjenja od $40 \% \mathrm{CO}_{2} \mathrm{u}$ odnosu na klasičan grad

- $\quad$ Korišćenje svemirske solarne elektrane - energija bi se prikupljala u svemiru i slala bi se nazad na zemlju

- Korišćenje dopunskih tehnologija obnovljive eneregije kao što su aerogeneratori, termalna $\mathrm{i}$ energija dobijena od snage talasa

Korišćenje okeana koji okružuje grad za hvatanje i skladištenje emisija $\mathrm{CO}_{2}$

Obimne mere reciklaže i tehnike obrade otpada, uključujući i prikupljanje otpada iz voda koje okružuju grad i stvaranje energije iz tog otpada

Ovakvom kombinacijom, bio bi stvoren „botanički grad koji neprekidno apsorbuje $\mathrm{CO}_{2}$ Green Float bio bi smešten u Pacifičkom okeanu bliže ekvatoru, kako bi koristio tamošnje vremenske uslove. Ćelije grada ne bi bile fiksirane za dno okeana već bi lagano plutale uokolo. Problem je što se sa realizacijom projekta moglo da se počne tek 2025 . godine.

Takođe, u Evropi, arhitekta Vensan Kalbo (Vincent Callebaut) obrađuje problematiku klimatskih izbeglica u okviru svog projekta Lilypad, ogromnog lokvanja koji može da pruži utočište za 50.000 stanovnika. Ovo ekološko ostrvo bilo bi ne samo autonomno, 


\section{$4^{\text {th }}$}

Contemporary achievements in civil engineering 22. April 2016. Subotica, SERBIA

već bi bilo i mobilno zahvaljujući preciznoj tehnologiji koja bi mu omogućila da prati morske struje.

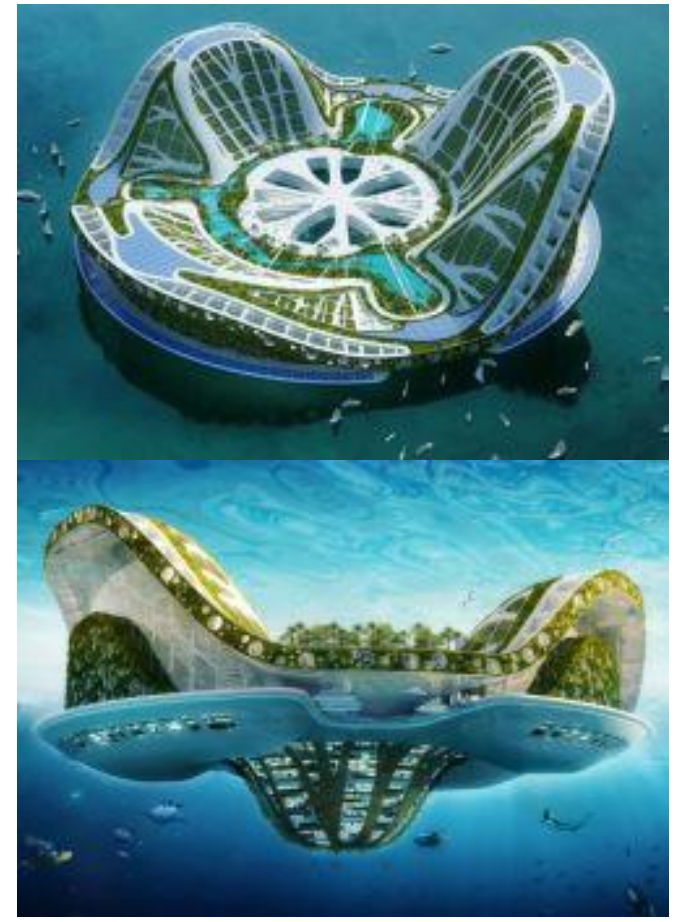

Slika 2. Lilypad

Holandija je specifična zemlja sa skoro polovinom teritorije ispod nivoa mora. Ovde su poplave sastavni deo života i upravo iz ove zemlje potiče jedno od mogućih rešenja. Ovde su kompanije predložile savršeno jednostavno rešenje - kuće na vodi. Tvrde da su ove kuće fleksibilne i da mogu podneti podizanje nivoa vode i do $5 \mathrm{~m}$. Čak su razvijena su dva modela: kuća na vodi kao brod i amfibija koja je na obali za vreme suvog vremena.Oba tipa kao bazu koriste šuplje betonske prizme i čelične stubove koji pomažu da kuće ostanu ukotvljene na jednom mestu jer bi se usled jakih struja brzo mogle naći na otvorenom moru. Struja i voda su sprovedene preko fleksibilnih cevi koje su napravljene tako da mogu da prate promene nivoa vode.

Dok u zemljama Južne Amerike, Afrike i jugoistočne Azije stanovništvo praktikuje gradnju plutajućih gradova na način svojih predaka, novi oblik plutajućih gradova, samodovoljnih i održivih, pokretnih i sa pozitivnim energetskim bilansom, možda bi mogao da se pojavi i da promeni naše shvatanje života.

Jedan od najatraktivnijih projekata, koji uzima u obzir činjenicu da će u bliskoj budućnosti kopna biti sve manje a mora sve više, jeste Subbiosfera 2, projekat koji je smislio londonski arhitekta Fil Poli. 


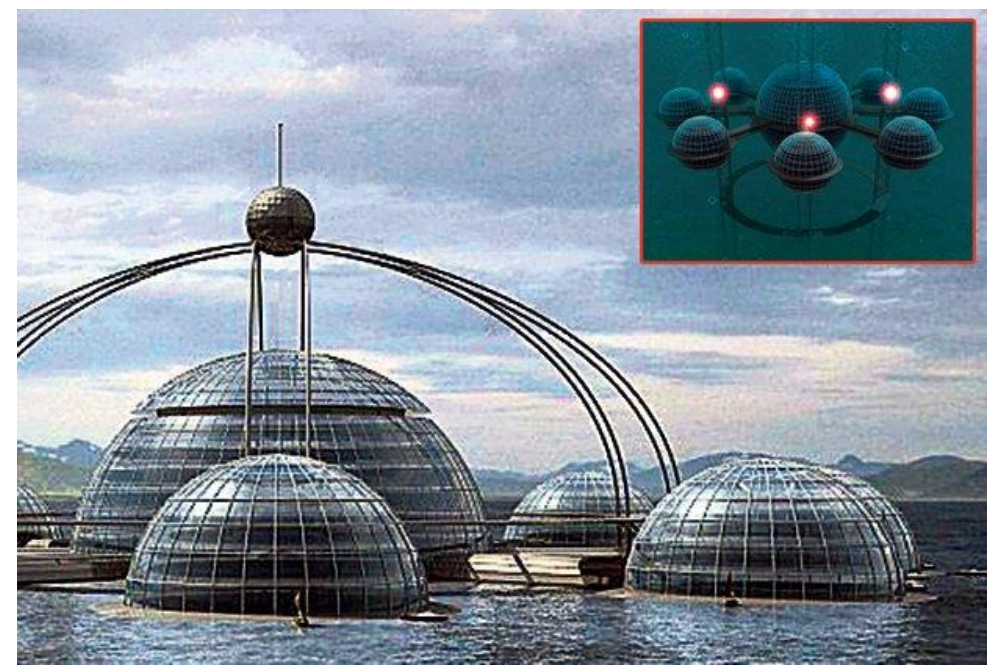

Slika 3. Grad pod vodom

Ovaj podzemni grad može biti dom za oko sto ljudi, a svi koji budu živeli u njemu biće potpuno nezavisni od spoljnog sveta, pošto će hranu, struju, vazduh i vodu za piće dobijati iz mora.

Integralno, fleksibilno i iznad svega adaptivno arhitektonsko-urbanističko projektovanje i multidisciplinarni prilaz sektoru urbanizma, arhitekture i pejzažnog urbanizma imaju kao krajnji efekat razvoj jedne potpuno nove arhitekture gradova koja se znatno razlikuje od tradicionalnih metoda stilske, funkcionalne i formalne analize. Pri tome, sama promena arhitektonskih paradigm podrazumeva promenu doživljavanja arhitektonskog prostora i objekata, preispitivanje definicije arhitekture kao nauke, veštine, umetnosti, pa i kulture. To vodi ka spremnosti za otvorenost i prijemčivost shvatanja koja vode ka arhitekturi atmosphere ili meteorološke arhitekture. Samim tim nastaje nova estetika izvan vizuelnog diskusa arhitekture, čije istraživanje uklkjučuje uvođenje analitičkih metoda i pitanja koja se tiču ekološke funkcionalnosti u skladu sa envajronmentalnim uslovima. Važan aspekt nove estetike savremene arhitekture tiče se društvene odnosno socijalne održivosti u kojem se pred arhitekturu postavljaju etički izazovi u vezi sa socijalnom odgovornošću, odnosom prema mestu i ekološkom svesnošću. [5].

Projektanti se opredeljuju, takođe, za nove tehnike angažovanja javnosti u procesu transformacije pejzaža u razvoju, smatrajući veoma važnim permanentnu obaveštenost i stalno učešće zajednice u generisanju i implementaciji projekta, što vodi ka formiranju novih urbanih iskustava, funkcija i aktivnosti. Pejzažne arhitekte, sprovodeći tokom rada istraživanja kojima se otkrivaju međuzavisnosti prirode i kulture, stvaraju urbane predele koji mogu biti valorizovani sa aspekta novostečenih kulturnih, socioloških i ekoloških karakteristika. Jasno je da su ekološka pitanja i duboko-etička i filozofska i da se rešenje problema, koje se tiče ekologije i opstanka civilizacije, odnosi i na neizbežnu promenu urbane kulture . Čini se da je antropolog, ekolog, kibernetičar Gregori Bejtson (Gregory Bateson) pre više od četiri decenije razmatrao ovaj problem 
Contemporary achievements in civil engineering 22. April 2016. Subotica, SERBIA

kada je govorio o stvaranju ,visoke civilizacije”[6] (koja će sadržati sve neophodno za fizičko, estetsko i kreativno zadovoljstvo ljudi, a čija će raznovrsnost proizvesti fleksibilnost neophodnu za odgovor na nepredvidive promene. Zdravom ekologijom Bejtson smatra kombinaciju fleksibilnosti životne sredine i ljudske civilizacije koja stvara tekući, složen, otvoren sistem u sadejstvu sa prirodnim sistemima koji ga okružuju. Bejtsonova vizija ekologije ne samo da anticipira željeno stanje, već nedvosmisleno, ukazuje na istorijske presedane ekološke estetike, koji su paradigma za definisanje savremene ekološke funkcionalnosti u skladu sa envajronmentalnim uslovima, a samim tim i estetike savremene arhitekture i urbanizma.

Danas je pejzaž postao objektiv kroz koji se posmatraju savremeni gradovi, a istovremeno je i medij preko kojeg se oni konstruišu. Višeznačni odnos pejzaža i arhitekture u uslovima postindustrijskih gradova postaje osnovno polazište projekata i planova, ne samo kroz saradnju arhitekata i pejzažnih arhitekata, već i kao osnov novih tehnika i koncepata projektovanja i novih formalnih strategija arhitekture i urbanizma. Međuzavisnost se ogleda i u projekcijama i pitanjima na koji način promene urbanog pejzaža pod uticajem klimatskih promena kao posledice ljudskih delatnosti, povratno uslovljavaju socio- kulturne promene? Da ekološki procesi mogu da inspirišu oblike urbanih naselja na način koji je efkasan, ekonomičan, lokalno prepoznatljiv i minimalno potrošački, u to smo se uverili dokazavši polaznu hipotezu da klimatske promene utiču na promenu urbanističko-arhitektonskog planiranja prostora. U povezivanju primenjene ekologije i stvaranju ekološke demokratije osnov je za stvaranje radikalno novih formi naselja, i to prvenstveno kroz potragu za fundamentima zadovoljavajućeg kvaliteta življenja. Metamorfoza urbanog pejzaža i ljudskih naselja, odvija se kroz primenu formi koje povezuju ekologiju i demokratiju, a koje se definišu kao omogućavajuće, fleksibilne i podstičuće.

\section{REŠENJA I PROMENA PARADIGMI}

Suočeni sa realnošću ostvarivanja nepovoljnog scenarija uticaja klimatskih promena na život ljudi, nameće se pitanje kako sprečiti ili usporiti dalje globalno zagrevanje, i uopšteno klimatske promene. Naravno, postoji veoma jednostavan odgovor na to, a to je smanjenje emisija štetnih gasova u atmosferu. Značajan doprinos u ovom smislu bi predstavljala i strogo kontrolisana seča tropskih šuma koje predstavljaju biljni regulator globalne temperature. Ali osnovni problem je u složenoj i teškoj realizaciji ovih mera. Zbog toga su zemlje donosile razne lokalne propise i međudržavne sporazume u cilju zaštite postojećeg sastava atmosfere. I danas postoje mnogobrojni propisi i rešenja o zaštiti, ali se u današnje vreme razmatraju i novi načini ublažavanja klimatskih promena.

Još jedna u nizu kampanja koje su radile na tome da se podigne svest ljudi o tome kako, i na koji način mogu pomoći kao pojedinci u ovoj velikoj akciji za očuvanje planete, jeste kampanja „Sat za našu planetu“ i kampanja Mladih istraživača Srbije, koji su u okviru projekta "Održivi transport" organizovali niz uličnih događaja koji su imali za cilj prvenstveno da se šira javnost informiše o klimatskim promenama i potrebi smanjenja emisije $\mathrm{CO}_{2}$. 


\section{ZAKLJUČAK}

Nije dovoljno reći samo da se klima na Zemlji menja $i$ da to ima dalekosežne posledice po čitavu planetu i sav živi svet na njoj, kao ni to da će se problemi rešiti određenim propisima i sporazumima. Nije samo bitno da sporazum postoji, već je potrebno da ga pojedinci shvate i realizuju na pravi način. Oni će samo tako i ispuniti zadato, a jedan od načina za to jeste upravo akcijama, pomoću kojih se podiže svest ljudi o situaciji u kojoj se nalazi planeta. Jer, ko veruje da nema uticaja na događanja u svom životu neće preduzimati ništa, situacije će se „događati“. Ali, oni koji veruju da bar u nekoj meri imaju mogućnost da utiču na svoj život, činiće sve što je da život učine. Posledice promene klime su vidljive i ozbiljne, zbog toga se moraju i preduzeti ozbiljne mere u rešavanju i sprečavanju istih. Pred arhitekturom i pred poslenicima u ovoj oblasti je ozbiljan i težak zadatak: mnoge forme, pravila i principi koji su do juče važili u arhitektonsko-urbanističkom planiranju, danas više ne važe ili ne mogu u punoj meri da se primene. Potrebno je prilagođavanje nastalim promenama u smislu podizanja kvaliteta života u urbanim sredinama, za šta je svakako odgovorna arhitektura.

\section{LITERATURA}

[1] Fourth Assessment Report of the Intergovermental Panel on Climate Change (IPCC), Summary for Policymakers, 2007.

[2] Nikolić, M.: Srbija pred izazovom globalnih klimatskih promena i njihovih posledica, Klimatske promene - studije i analize, Evropski pokret u Srbiji, 2010.

[3] WWF (Svetski fond za prirodu), Procena ranjivosti na klimatske promene-Srbija, Centar za unapređenje životne sredine, 2012.

[4] Cappelli, L. i Guallart, V. (2010). Self Sufficient City - Envisioning the habitat of the future.Actar, IAAC, Barcelona.

[5] Blagojević, Lj., i Ćorović, D.: "Klimatske promene i estetika savremene arhitekture", u monografiji "Uticaj klimatskih promena na planiranje i projektovanje", Univerzitet u Beogradu, Arhitektonski fakultet, Beograd, 2011.

[6] Bateson, G. (1987). „Ecology and Flexibility in Urban Civilization”. In: G. Bateson. Steps to an Ecology of Mind (1972). Jason Aronson Inc., Northvale, NJ / London, 347-361

\section{IMPACT OF CLIMATE CHANGE ON THE ARCHITECTURE OF CITIES}

Summary: This paper discusses the impact of climate change on the omnipresent changes in architecture, primarily in urban areas. Its hypothesis is that the awareness of climate change necessitated the development of new and innovative techniques, technologies, principles of ecological architectural and urban design, or changes to the 


\section{$4^{\text {th }}$}

Contemporary achievements in civil engineering 22. April 2016. Subotica, SERBIA

concept of contemporary architecture of cities. Modern architecture in the light evident climate change, not trying to be a "Knowledgeable, correct and magnificent play of forms assembled in the light" (Le Corbusier), but seeks to influence the environment by creating a micro-climate zones in the interior and exterior space, insisting, at the same time, the zero energy consumption. Therefore, before modern or even more, in front of the architecture in the future there is a requirement for sustainability, in collaboration with the sustainable development environments and improved environmental awareness in environmental protection.

Keywords: architecture, urban environment, climate change 